\title{
Theme and Rheme in Mandailing Songs Texts by Odang and Masdani
}

\author{
Shoufi Nisma Dewi \\ English Applied Linguistic Study Program \\ Universitas Negeri Medan \\ Indonesia \\ shoufinisma@gmail.com
}

\begin{abstract}
Language accommodates as a sender of message to reader as the target information. It is how to transfer message like ideas, thoughts, needs, purpose and others. There are three functions of language which are called as metafunction of language. There are three types of Theme, namely ideational/topical Theme, textual Theme, and interpersonal Theme. The objective of this research was to identify the realization of Theme and Rheme in Odang and Masdani's song lyrics. The method used in this research was descriptive qualitative research method. The data of this research were the types of Theme found in Odang and Masdani's Song Lyrics. There are three songs lyrics as the source of data. In analyzing the data, the researcher used the framework proposed by Halliday. The data were analyzed through following steps: 1) segmenting the data into clauses. 2) Identifying the Theme and Rheme for each clause. 3) Describing the types of Theme in the Lyrics. The results found that there were 70 clauses showing the three types of Theme in the song lyrics. They are topical, interpersonal and textual Theme. Unmarked topical Themes $(60 \%)$ are mostly used by the Mandailing song lyrics. followed by textual Theme $(22.8 \%$,$) , marked Theme (8.5 \%)$, and interpersonal Theme $(8.5 \%)$. It seems that the Mandailing song text tend to use subject as Theme.
\end{abstract}

\section{Keywords: Theme and Rheme; Song Lyrics; Mandailing}

\section{INTRODUCTION}

The language used in Indonesia diverse from Sabang to Merauke, as well as the national language, official language and regional languages, such as Minangkabau Language, Javanese, Sundanese, Aceh, Malay, Batak and etc. In communicating we can express directly and indirectly. According to the observation, it was found that people tend to communicate indirectly. They used media to express their feeling and emotion, one of them is by using song. Mandailing song is popular to be listened in Mandailing and South Tapanuli Area. Many people created their song by using their native language. This phenomenon showed us that many people interested to use a song as media to express their feeling and emotion. It can be seen from top of Mandailing album collection. For example the duet album of Odang and Masdani is the most popular album in Mandailing.

The researcher used Theme and Rheme in systemic functional linguistic (SFL) theory because Theme and Rheme are commonly used in every text especially in song text. Textual is an organizing message that has relevant to context in linguistic and social [1]. The analysis types of thematic structure was related to the types Theme of song texts. This study focused on Theme found in Mandailing songs. The
Mandailing song texts shaped by arrangement of the Theme and explained the structure in The Mandailing song.

Textual function consists of Theme and Rheme. It plays an important role in developing and creating meaning of a language in Mandailing song. The Mandailing song texts shaped by arrangement of the Theme and explained the structure in The Mandailing song. To find out the Theme and Rheme in the song texts, the researcher should have knowledge about the text. Here the researcher found Theme in Mandailing song text by Odang and Masdani. Based on the analysis, the researcher found the preliminary data as the following:

\begin{tabular}{|l|l|l|}
\hline Text & $\mathrm{Hu}$ & Ida salibon mi \\
\hline Glossary & $\mathrm{I}$ & See your eyebrow \\
\hline Analysis & Theme & Rheme \\
\hline Torag ari & $\begin{array}{l}\text { dongan murmahancit so jungada cukup } \\
\text { kaporluanon }\end{array}$ \\
\hline Morning & plus suffering never enough needs \\
\hline Marked Theme & Rheme \\
\hline
\end{tabular}

In a song often uses metaphors. So it is sometimes difficult to understand the meaning of the song. If we know the theme in the song indirectly we know the meaning in the song. Based on the table above the Theme is the element that serves as the point of departure of the message; it is located and oriented the clause within its context. The speaker chose the Theme as his or her point of departure was to guide the addressee in developing an interpretation of the message; by making part of the message prominent as Theme, the speaker enables the addressee to process the message.and the Theme is not only the subject of the clause. In line Halliday and Matthiessen said that Theme is the starting case of the message. [2]

The analysis types of thematic developments are discussed to see the types of Theme in Mandailing song, the analysis of this is once in a while happen because some other researcher might concentrate on the novel, newspaper, articles which simple to be found in all around, but the contending of song in only take place in Mandailing song which means this is very limited action be happened therefore the discoveries could be very different, these are other reasons why researcher study about this topic. The problem of this research was formulated as "What type of Theme and Rheme used in Mandailing songs of Odang and Masdani?" 
Based on the reason, this research was focused on the analysis in Mandailing song text especially in duet album from Odang and Masdani by considering Theme in the song text.

\section{A. Metafunction}

Metafunction can be explored in written and oral language, and it works in the clause, sentence, phrase because metafunction state that they simultaneously encode three standards meaning. Halliday said that the three functional components of meaning, ideational, interpersonal, and textual, are realized throughout the grammar of a language. Metafunction as three types of meaning within grammatical structure of a clause[3]. A clause is a unit in which three of different kinds are combined, namely ideational refer to clause as representation. Interpersonal function refers to clause as an exchange. And textual refers to clause as a message.

\section{a. Organizing Message : Theme}

The system of Theme belongs to the textual metafunction of language. In English, the Theme is indicated by position in the clause; the Thematic status is put in the first element of a clause and Rheme follows. According to Deterding and Poedjosoedarmo, "Textual meaning is expressed by thematic structure (the identity of Theme, what we are talking about, and Rheme, what we are saying about it), in another word it is called as clause as message"[4]. It considers first the one which gives the clause its character as a message or thematic structure. Theme can be defined as point of departure and the rest of the message of the clause; after the point of departure is called Rheme [5]. It is the point of departure of a message with which the clause is concerned, not so much constituent as a movement from the beginning of the clause. Halliday believes that each clause conveys a message that has two parts, i.e., what comes first or the Theme, and what comes last or the Rheme. The Theme usually constrains given information and the Rheme, new information.

As stated by Johnstone, there are several ways of labeling these functional parts of sentences, depending on the particular formulation of the idea; some functional grammarians talk about the differences between "given" and "new" information, others about "Theme" and "Rheme", others about "topics" and "comments". Further he explained that sentences move from familiar to the less familiar, or from the "what" to the "what about it"[6]. It reflects that people appear to process information by first identifying what is being talked about and then attending to what is being said about it.

\section{B. Type of Theme}

Gerot and Wignell classified Theme into three types. They are Ideational (Topical), Interpersonal and Textual Theme[7].

\section{(1) Ideational Theme}

Ideational or Topical Theme can be recognized as the first element in the clause that expresses some kinds of 'representational' meaning. It means that when an element of the clause to which transitivity function can be assigned occurs in first position in a clause, it is regarded as a topical Theme.

Topical Theme may be nominal group, nominal group complexes, adverbial groups, prepositional phrases or embedded clause. A topical Theme which is a subject is called unmarked topical Theme while one which is not a subject is called marked topical Theme. Below is the example of ideational Theme.

Unmarked Topical Theme

Nominal group as a Theme.

\begin{tabular}{|l|l|}
\hline Jack & Went up the hill \\
\hline Theme & Rheme \\
\hline
\end{tabular}

Nominal group complex as a Theme

\begin{tabular}{|l|l|}
\hline Jack and jill & Went up the hill \\
\hline Theme & Rheme \\
\hline
\end{tabular}

Embedded clause as Theme.

\begin{tabular}{|l|l|}
\hline (what jack and jill did) & Was go up to hill \\
\hline Theme & Rheme \\
\hline
\end{tabular}

Marked Topical Theme

Adverbial as Theme

\begin{tabular}{|l|l|}
\hline Down & Jack fell \\
\hline Theme & Rheme \\
\hline
\end{tabular}

Prepositional Phrase as Theme

\begin{tabular}{|l|l|}
\hline Up the hill & Jack and jill went \\
\hline Theme & Rheme \\
\hline
\end{tabular}

Complement as Theme

\begin{tabular}{|l|l|}
\hline His crown & He broke \\
\hline Theme & Rheme \\
\hline
\end{tabular}

From the statements above, it can be summed up that there are two types of topical Theme. They are marked and unmarked topical Theme. We called it unmarked topical Theme, if subject is used as a Theme. In this case, it can be nominal group, nominal group complex, and embedded clause. We called it marked topical Theme if the Theme is not a subject. It can be adverb, prepositional phrase, and complement as a Theme.

\section{(2) Interpersonal Theme}

Interpersonal elements occurring before the topical Theme are also thematic. An interpersonal Theme may be (i) vocative (ii) modal adjunct (iii) finite or wh-elements (mood marking)

A vocative is any item, typically (but not necessarily) a personal name that is used to address; it may come more or less anywhere in the clause; and is Thematic if it is proceed in the topical Theme. Below is the example.

\begin{tabular}{|l|l|}
\hline John we & Want to meet you \\
\hline Vocative topical & Rheme \\
\cline { 1 - 1 } Theme & \\
\hline
\end{tabular}

A modal adjunct expresses the speaker's judgment or evaluation of the relevance of the message, e.g. probably, 
certainly, occasionally, of course, no doubt, honestly, surprisingly, by chance, in my opinion, frankly, etc.

\begin{tabular}{|l|l|c|}
\hline Perhaps & We & Can do it \\
\cline { 1 - 2 } Modal & Topical & \multirow{2}{*}{ Rheme } \\
\cline { 1 - 1 } Interpersonal & & \\
\hline
\end{tabular}

A mood marking Theme is a finite verbal operator, if preceding topical Theme, or a Wh-interrogative (or imperative Let's) when not preceded by another experiential element (i.e. when functioning simultaneously as topical Theme), for example;

\section{a. Finite}

Have you done your homework?

\begin{tabular}{|l|l|c|}
\hline Have & You & Done your homework \\
\hline Interpersonal & Topical & Rheme \\
\hline \multicolumn{2}{|l|}{ Theme } & \\
\hline
\end{tabular}

\section{(3) Textual Theme}

Textual Themes relate the clause and its context. They almost always constitute the first part of the Theme, coming before any interpersonal Theme. Textual Theme can include a continuative (yes, no, well, oh, etc. - discourse particles), a conjunction (Structural Theme; paratactic; and, but, either, then, yet, or, etc., hypotactic: when, because, since, while, although, if, etc.), and/ or a conjunctive adjunct (that is, also, in addition, nevertheless, on the other hand, etc.).These are elements which do not express any interpersonal or experiential meaning, but which are doing important cohesive work in relating the clause to its context. Below is the example.

\section{a. Conjunction.}

\begin{tabular}{|l|l|l|}
\hline Althoug & \multicolumn{1}{c|}{ it } & \multicolumn{1}{c|}{ is difficult to do. } \\
\hline Textual & Topical & Rheme \\
\hline Theme & \\
\hline
\end{tabular}

b. Continuative and conjunctive

\begin{tabular}{|l|l|l|l|}
\hline Well & $\begin{array}{l}\text { On the other } \\
\text { hand }\end{array}$ & We & Can do that \\
\hline Continuative & Conjunctive & Topical & Rheme \\
\cline { 1 - 1 } & \\
\hline
\end{tabular}

Similar to Gerot and Wignell's opinion, Fries classified Theme into three types. They are experiential, interpersonal and textual Theme[8]. Experiential or Topical Theme can be participant, process or circumstance. Interpersonal Theme can be vocative, modal adjunct, finite operator and Wh-(interrogative). Textual Theme can be continuative, structural conjunction, Wh-relation and conjunctive. The Theme can also be classified according to its internal structure. In this case, Halliday classifies Themes into Simple Theme and Multiple Theme[9].

\section{a. Simple Theme}

We call a Theme as a simple Theme if the Theme of the clause consists of just one structure element and that element is represented by one-unit - one nominal group, adverbial group or prepositional phrase. In addition to this, Butt, Fahey, Feez, Spinks, and Yallop state that a simple Themecontains only an experiential or topical element[10]. The example of this type is as follows;

\begin{tabular}{|l|l|}
\hline In the ground tony & $\begin{array}{l}\text { Small creatures live and breathe has a } \\
\text { book }\end{array}$ \\
\hline Theme & Rheme \\
\hline
\end{tabular}

Based on the definition and example above, it can be concluded that if the Theme of the clause consists of more than one type of Themes, we call it multiple Theme. In this case, it can consist of textual, interpersonal and topical element. Textual and interpersonal come before topical element.

\section{b. Multiple Theme}

We call the Theme as multiple Theme if the Theme can then be subdivided into textual, interpersonal and topical element Multiple Theme is the Theme that extends from the beginning of the clause up to (and including) the first element that has function in transitivity which is called 'Topical Theme [10]. In other words, multiple Theme consists of the topic together with anything else that comes before it. Following is the example of multiple Theme.

\begin{tabular}{|l|l|l|}
\hline Nevertheless & The alternative & Was not simple \\
\hline Textual & Topical & Rheme \\
\cline { 1 - 1 } Theme & \\
\hline
\end{tabular}

Based on the above definition and example, I conclude that if the Theme of the clause consists of more than one type of Themes, we call it multiple Theme. In this case, it can consist of textual, interpersonal and topical element. Textual and interpersonal come before topical element.

\section{Song Lyric}

Song lyric is the set of words that make up a song, usually consisting of verses and choruses. The meaning of lyrics can either explicit or implicit. The word lyric came to be used for the "words of a song". The common plural (perhaps because of the association between the plurals lyrics and words), predominates contemporary usage. Use of the singular form lyric to refer to a song's complete set of words is grammatically acceptable. However, it is not considered acceptable to refer to a singular word in a song as a lyric.

Indonesia has many languages, customs and religions. Indonesia has been famous for its various cultures and ethnics since long time ago. Each group has its own characteristics. Mandailing is one of the ethnics in Indonesia which is located in North Sumatera.

Mandailing people are usually conveying their message, idea, through songs. Mandailing people do not directly say, but they will use song as medium to express their feeling. Nowadays, people in Mandailing still sing Mandailing songs in order to express their feeling and to maintain their own culture. 


\section{RESEARCH METHOD}

The method used in this research was descriptive qualitative research method. The data of this research were the types of Theme which was found in Odang and Masdani's Song Lyrics. There are three song lyrics as the data source. In analyzing the data, the researcher used the framework proposed by Halliday's. The data were analyzed through some steps, they were: 1) Segmenting the data into clauses; 2) Identifying the Theme and Rheme for each clause; 3) Describing the types of Theme of Lyric expressed in that song. The data of this research was the lyrics of the mandailing songs. As stated by Arikunto, "Data sources is the subject from which the data are obtained"[11]. The sources of data were mandailing songs by Odang and Masdani in the form of song lyric taken from the internet. The researcher watched the video of mandailing song. There were three songs taken from Odang and Masdani entitled Supir Motor, Ujian Sian Tuhan and Bujing Nauli. Odang and Masdani is the famous singers in Mandailing.

Three steps were conducted in order to collect the data, namely watching, downloading, printing, transcribing. The video of the mandailing songs are downloaded from youtube. It was downloaded in July 2017. The video were played many times to transcribe the lyrics. The lyrics were categorized into types of the Theme and Rheme according Halliday's theory. It was taken through document that is written in the text of mandailing song video.

\section{FINDING}

The data used in this research were the song lyrics of Odang and Masdani. Theme analysis was done to provide the relevant answer to the first research question posed in the previous part: what type of Theme and Rheme used in Mandailing songs of Odang and Masdani. The types of Theme of the mandailing song text can be seen in the following table:

\begin{tabular}{|l|l|l|l|l|l|}
\multicolumn{2}{c}{ TABLE I: The Frequency Of Each Type Of Theme } \\
\hline \multirow{2}{*}{ Text } & \multirow{2}{*}{$\begin{array}{l}\text { Number } \\
\text { of clause }\end{array}$} & Textual & $\begin{array}{l}\text { Interpers } \\
\text { onal }\end{array}$ & \multicolumn{2}{|c|}{ Topical } \\
\cline { 3 - 6 } & & & & Marked & Unmarked \\
\hline 1 & 19 & 6 & 2 & 4 & 7 \\
\hline 2 & 30 & 10 & 0 & 2 & 18 \\
\hline 3 & 21 & 0 & 4 & 0 & 17 \\
\hline Total & 70 & 16 & 6 & 6 & 42 \\
\hline$\%$ & 100 & $22.8 \%$ & $8.5 \%$ & $8.5 \%$ & $60 \%$ \\
\hline
\end{tabular}

From Theme analysis, the researcher found that the types of Theme in song text by Odang and Masdani are dominated by unmarked topical Theme; 42 out of 70 or $60 \%$. It means that most of Theme used by Odang and Masdani songs texts were subject as Theme. The second type of Theme in Odang and Masdani song text was textual Themes. There were 16 clauses out of 70 or $22.8 \%$. It means that the song text used either continuative, conjunction, or conjunctive adjunct in Mandailing song text in 16 clauses. The elements came before interpersonal or topical Theme. The third types of Theme mandailing songs texts by Odang and Masdani are marked topical Themes. There are 6 clauses out of 70 clausese or $8.5 \%$ which means that the Mandailing songs texts by Odang and Masdani use adverbial, prepositional phrase or complement as Theme. The examples of the analysis can be seen in the following parts.

\section{a. Unmarked topical Theme}

Unmarked topical Theme is clause in which subject is used as a Theme.

\begin{tabular}{|l|l|}
\hline $\mathrm{Hu}$ & ida silibon mi \\
\hline $\mathrm{I}$ & See your eyebrow \\
\hline Unmarked Theme & Rheme \\
\hline
\end{tabular}

In clause "hu ida silibon mi (I see your eyebrow)". "I" belongs to unmarked topical Theme because the clause refers to person or nominal group. As we know that unmarked topical Theme is a Theme that explains nominal group, nominal group complex, and embedded clause.

\begin{tabular}{|l|l|}
\hline $\mathrm{Hu}$ & ida palakka mi biasa- biasa tarida anggun \\
\hline $\mathrm{I}$ & see your usual but graceful way of walking \\
\hline Unmarked Theme & Rheme \\
\hline
\end{tabular}

In clause "hu ida palakkami biasa-biasa tarida anggun (I see your usual but graceful way of walking)". "I" belongs to unmarked topical Theme because the clause refers to person or nominal group.

\section{b. Marked topical Theme}

Marked Theme is Theme that is something other than the subject. It can be adverbial, prepositional phrase or complementas Theme

\begin{tabular}{|l|l|}
\hline Torag ari & $\begin{array}{l}\text { dongan murmahancit so jungada cukup } \\
\text { kaporluanon }\end{array}$ \\
\hline Morning & plus suffering never enough needs \\
\hline Marked Theme & Rheme \\
\hline
\end{tabular}

In clause "Torag ari dongan murmahancit so jungada cukup kaporluanon ( Morning, plus suffering never enough needs)". "Morning" belongs to marked topical Theme because the clause refers to adverbial. As we know that marked topical Theme is a Theme that explains adverbial, prepositional phrase, and complement.

\begin{tabular}{|l|l|}
\hline Sipirok & mangida ho pasti mandok onang jogi nai \\
\hline Sipirok & see you must say onang so beautiful \\
\hline Marked Theme & Rheme \\
\hline
\end{tabular}

In clause "sipirok mangida ho pasti mandok onang jogi nai (Sipirok see you must say onang so beautiful)". "Sipirok" belongs to marked topical Theme because the clause refers to adverbial.

\section{c. Textual Theme}


Textual Theme related the clause to its context. It can be continuative, conjunctive adjunct or conjunction.

\begin{tabular}{|l|l|l|}
\hline Nada & $\mathrm{Au}$ & sobar mangidasa \\
\hline No & $\mathrm{I}$ & Can not patient to see it \\
\hline Textual & Topical & Rheme \\
\cline { 1 - 1 } Theme & \\
\hline
\end{tabular}

In clause "nada au sobar mangidasa (No, I cannot be patient to see it)". "No" belongs to textual Theme because the clause refers to continuatives. As we know that textual Theme is a Theme that explains a continuative (yes, no, well, oh, etc. - discourse particles), a conjunction (Structural Theme; paratactic; and, but, either, then, yet, or, etc., hypotactic: when, because, since, while, although, if, etc.), and/ or a conjunctive adjunct (that is, also, in addition, nevertheless, on the other hand, etc. "I" belongs to unmarked topical Theme because the clause refers to person or nominal group.

\begin{tabular}{|l|l|}
\hline Baen & na dung ima dongan na hum denggan \\
\hline Because & It is the best \\
\hline Textual Theme & Rheme \\
\hline
\end{tabular}

In clause "Baen na dung ima dongan na hum denggan (Because it is the best)". "Baen (because)" belongs to textual Theme because the clause refers to Hypotatic.

\section{d. Interpersonal Theme}

Interpersonal Theme include modal adjunct, vocatives, finite or Wh-elements as a Theme of the clause.

\begin{tabular}{|l|l|}
\hline Pasti & mandok ya habibi \\
\hline Certainly & Says ya habibi \\
\hline Interpersonal Theme & Rheme \\
\hline
\end{tabular}

In clause "Pasti mandok ya habibi" belongs to Interpersonal Theme because the clause refers to modal adjunct. As we know that Interpersonal Theme is a Theme that explains vocative, modal adjunct, finite or wh- elements (mood marking)

\begin{tabular}{|l|l|}
\hline Ahado & maksud mi \\
\hline What & Do you mean \\
\hline Interpersonal Theme & Rheme \\
\hline
\end{tabular}

In clause "Aha do maksud mi ( What do you mean)" belongs to Interpersonal Theme because the clause refers to mood marking.

The last types of Theme written by Mandailing song text are interpersonal Themes. There are 6 clauses out of 70 clausese or $8.5 \%$. in this case the Mandailing song text by Odang and Masdani put either vocative, modal adjunct or mood adjunct in initial position. The song text put Theme as thematic.

\section{DISCUSSION}

Based on the data analysis, it can be concluded that there are three types of Theme applied by the Mandailing song text. They are unmarked, marked, textual and interpersonal Theme. This study was supported by some previous research. The research about SFL in Theme analysis had been conducted by the some researchers, Potter (2016) in her journal entitled "Ideological representations and ThemeRheme analysis in English and Arabic news reports: a systemic functional approach" focused on Halliday's functional model of Theme-Rheme in Arabic and apply his understanding of the clause as a message to English and Arabic news reports. The analysis compares and contrasts the thematic and information structures in 14 reports ( 7 in English and 7 in Arabic), which were published between 25 and 27 September 2006 by mainstream online news media, including Al-Jazeera and the British Broadcasting Corporation.

Furthermore, it is also supported by Wang (2007:164) stated in his research, that by analyzing ThemeRheme in a text, the students could learn to perform similar analysis in their own writings and thus improve cohesion in their own work. The relationship between Theme and Rheme is essential in creating a cohesive text.

\section{CONCLUSION}

Based on the finding and discussion of the research, it can be concluded from the result of the whole description data the discussion as the answer of the statement of the problems about the types of Theme in Odang and Masdani Mandailing's song lyrics. Based on the analysis, the researcher concluded that most types of Theme in Odang and Masdani Mandailing's song lyrics used topical Theme, especially unmarked topical Theme. It could be seen from 70 clauses found 42 unmarked topical Themes, 6 marked topical Themes, 16 textual Themes and 6 interpersonal Themes. After analyzing the types of Theme in "Odang and Masdani learn to Mandailing's song lyrics". The percentage of unmarked topical Themes (60\%). It is mostly used by the Mandailing song text. Followed by textual Theme $(22.8 \%$,) marked Theme $(8.5 \%)$, and interpersonal Theme $(8.5 \%)$. It seemed that the Mandailing song text tend to use subject as Theme. The interpretation of the song lyrics depicted the narration of the composer's life.

\section{REFERENCES}

[1] Halliday,M.A.K.1985 An Introduction to Functional Grammar. London: Edward Arnold.

[2] Halliday, M.A.K. 2004. An introduction to functional grammar, 3rd ed. London: Arnold.pp 65

[3] Halliday, M.A.K. 1994. An Introduction to Functional Grammar. Second Edition London: Edward Arnold.pp 179

[4] Deterdin, David and Poedjosoedarmo, Gloria. The grammar of English. Singapore: Prentice Hall, 2001

[5] Halliday, M.A.K. 1994. An Introduction to Functional Grammar. Second Edition London: Edward Arnold.pp 181

[6] Johnstone, B. 2002. Discourse Analysis. Massachusette: Blackwel. Pp 99

[7] Gerot, L and Wignel, P. 1994. Making Sense of Functional Grammar. Sydney: Gerd Stabler. pp.103

[8] Fries, P. 1996. On Theme, Rheme and Discourse Goals. In M. Coulthard (Ed) Advances in Written Text Analysis. PP. 229- 249. London: Routledge.

[9] Halliday, M.A.K. 1994. An Introduction to Functional Grammar. Second Edition London: Edward Arnold.pp 185 
[10]Butt, D., Fahey, R., Feez, S., Spinks, S., and Yallop, C. 2000. Using Functional Grammar . an Explorer's Guide. $\quad$ Sydney: National Centre for English Language Teaching and Research.

[11]Arikunto, Suharsimi. (1996). Prosedur Penelitian Sosial: Suatu Pendekatan Praktik. Jakarta: PT. Bina Aksara.pp 135 